\title{
Folklore and Public Archaeology in the UK
}

\author{
Tina Paphitis \\ Institute of Archaeology, UCL, London, UK
}

This paper presents the potential for folklore to enrich studies of, and participation in, public archaeology. Referring to the varied approaches to public archaeology in the United Kingdom, and focusing on sites and landscapes, it will lay out the current status of folklore in five key areas of public archaeology: the history of archaeology, multivocality, historical consciousness, the archaeological imagination/representation, and heritage management. This paper will explore how key thoughts and approaches in folkloristics might not only contribute to these areas, but can radically enhance how we look at public archaeology historically, dialogically, and interpretively. Alongside this, those countries with well-developed folkloristic and ethnological research departments might con-sider ways of expanding their approaches to public archaeology, and engage in cross-disciplinary research investigating the complex and multi-faceted relationships with and representations of the past in the present.

Keywords: folklore, public archaeology, ethnographic archaeology, history of archaeology, historical consciousness, archaeological imagination, multivocality

\section{Introduction}

In 1980, archaeologist Leslie Grinsell stated that researchers should be engaged in 'the recovery of folklore heard by archaeologists in the course of fieldwork or during their excavations. Ideally, each archaeological excavation should have a recorder of folklore' (Grinsell, 1980: 213). Grinsell had begun a survey of the folklore of prehistoric sites in Britain before the Second World War (Grinsell, 1937 and 1939), when it was a popular academic notion that contemporary folklore could be used to infer the 'mentality' of the prehistoric peoples to whom such sites are attributed, or were 'remnants' of prehistoric beliefs. When his Folklore of Prehistoric Sites in Britain was finally published in 1976, it to some extent maintained this viewpoint. However, by the time he makes the above statement four years later, he realizes that such inferences were not only erroneous, but dangerous, and thus his suggestion here was in the main a reflection of his concern that local traditions were at risk of being lost, particularly with the apparent precedence given to archaeological investigation and interpretation. Whilst his primary concern here is with the salvaging of local folklore, what he proposes is today clear to us as a potential exercise in public archaeology. Almost forty years later, however, we see very little in the way of engaging the public at archaeological sites through folklore. Why? How do we practically undertake what Grinsell proposes, and to what end does this aid public archaeology and archaeology in general?

Focusing on sites and landscapes, this paper proposes practical ways in which folklore not only enriches but can be fundamental to the study and practice of public archaeology. ${ }^{1}$ I emphasize that this paper concentrates on the situation in the United Kingdom, acknowledging that, in the rest of Europe and internationally, folklore and archaeology have seen much closer relationships than here. I will focus on five specific areas of public archaeology: the history of archaeology, multivocality, historical consciousness, archaeological imagination/representation, and heritage management. Within these, I will show how folklore is a form of what I call retrospective, dialogic, and interpretive public archaeology and posit practical ways in which folklore can be engaged within it.

Although mainly studied and viewed today as separate phenomena, archaeology and folklore have close connections, not least observed in the enactment and repro-duction of various customs at or about archaeological sites. It has often been asserted that folklore about archaeological sites arise when previous knowledge about them has been lost (Hayman, 1997: 23; Symonds, 1999: 115; see Fleure, 1948: 74), although this view is far too simplistic, since folklore arises from meaningful engagements with places in particular contexts, rather than ignorant explanations for the presence of a site. The importance of archaeological sites to various people is well expressed in folklore warning of (typically supernatural) retribution for their disturbance (see various examples in Grinsell, 1976a). Such folklore 
has acted as a form of preventative conservation, since many sites might have been destroyed had such superstitions not been in place, and instances where monuments have been destroyed have also resulted in the persecution of the destroyer by the local community, due to the folkloric significance of the monument (see, for example, Hayman, 1997: 21-22 on the destruction of the Stone of Odin, Orkney). Similarly, archaeologists might consider how traditional beliefs may result in damage or destruction to archaeological sites, thus there is a need to under-stand local folklore and to engage in conversations about it. The connections between archaeological sites and folklore, then, are evident in the everyday consciousness and experience of certain groups, but the public archaeological study of this is often overlooked (Wallis \& Lymer, 2001a: xiii).

It is not uncommon to read of the marginality of folklore in archaeological research, and of the occasional support for including folklore in various investigations (see especially Gazin-Schwartz \& Holtorf, 1999). Yet, in the main, we get no closer to the 'normalization' of folklore's presence in archaeology. I would argue that, in part, this has much to do with the view that folklore is a 'thing' to be included, rather than as a body of material and carefully developed field of numerous approaches that are integral to various aspects of archaeology, particularly to public archaeology. Further, it is seen that the inclusion of folklore in archaeology is oftentimes little more than paying lip service to a field that can, at best, give researchers another notch in their publication bedposts and tick boxes for 'public engagement' requirements in research grants. Another common problem here is that those working outside the field of folklore (and even those within) have no clear conceptualization of what folklore 'is', making its dismissal in archaeology easy, and its misuse uncomfortably frequent. Though draconian, it is necessary, therefore, for us to begin with how folklore is here defined, and may be used by other researchers interested in the field.

\section{The 'Folk' and their 'Lore'}

To illustrate one misconception of folklore and folklore studies within academic archaeology, I will begin here with an anecdote. My first presentation about my doc-toral research in 2010 on my proposed investigation into the folklore of archaeological sites (Paphitis, 2014) to a group of other archaeology doctoral candidates detailed my research base, aims, questions, methods, and so on. As is customary after such a presentation, the floor was opened to questions. The first I received was phrased thus: 'so you're talking about ... peasants?'

Perhaps being in a British institution did not quite help in this context. Academic folklore studies in England are far from widespread, with learned societies such as the Folklore Society and English Folk Dance and Song Society (EFDSS) the mainstay of researchers in the field, who are scattered across history, anthropology, archaeology, English, sociology, and cultural/area studies departments, or are, in large part, independent researchers. Departments concerned with aspects of folk-lore studies in Scotland (especially Aberdeen's Elphinstone Institute), Northern Ireland and Wales are strongly regionally based, so one's engagement with folklore might only occur if they have a specific interest in these regions. The National Centre for English Cultural Tradition, University of Sheffield, closed in 2013, although the Centre for Contemporary Legend, established at the University of Sheffield in 1982, remains as a research centre at Sheffield Hallam University. An MA in Folklore Studies at the University of Hertfordshire, launched in 2019, has contributed to trying to narrow this gap in academic folklore studies in England. Comparatively, other institutions in Europe and beyond maintain a strong tradition of folkloristic and ethnological studies. Germany and the Nordic countries, for example, have maintained strong folkloristics departments and research centres, and, in turn, developed excellent research across archaeology and folklore. Yet the UK is arguably a stalwart in public archaeology, so how can there be such disconnect between the 'folk' of archaeology and the 'public' engaged in traditional cultural practices?

It was at this point after my presentation that I realized that subsequent talks to non-folklorists pertaining to my work would perhaps require a definition of folklore. Whilst such definitions are not usually necessary when addressing folklorists, it is by no means the case that folklorists themselves agree on a single definition of the discipline: debates have and continue to rage over the past two or so centuries 
(see, for example, various definitions collated by the American Folklore Society, n.d.). It may therefore be unsurprising that archaeologists have no clear grasp of folklore and its usage in their own studies. Though, in my experience of talking to the public about my research, the public themselves have no difficulties in under-standing what folklore 'is' (at least, what its materials are). A researcher might thus do well to devise a working definition of folklore in order to clarify their position and meaning. Here, then:

Folklore is the creation, enactment and reproduction of traditions of two or more people sharing one or more commonalities in relation to social, cultural, religious, political, economic and/or environmental contexts, transmitted orally, visually, by imitation or by other practised-based and active means. 'Folklore' may also be used as a shorthand reference to 'folklore studies' or 'folkloristics': the collection, study, analysis and interpretation of this material. The word 'folklore' is used, therefore, as a reference to the discipline and the materials of study of that discipline (after Paphitis, 2014: 54)

Or, to offer a pithier definition from Lucy Long (2015: 2): 'folklore is the processes and products through which an individual meaningfully connects with [their] past, place and other people'. In this definition, 'folklore' might easily be replaced with 'public archaeology' for an adequate definition of the latter field of study.

Whilst folklore, like archaeology, developed out of the 'popular antiquities' of antiquarianism, the coiner of the term 'Folk-Lore', William Thoms, ${ }^{2}$ predominantly referred to verbal and narrative forms (Thoms, 1846: 882). Thoms's aim was to create the equivalent of a Grimm mythology in Britain, and elected the use of 'a good Saxon compound' to refer to the collection and study of 'the Lore of the people' (Thoms, 1846: 862, 882), that is, the peasant classes possessing a timeless 'natural relationship' with the land, illustrating the nationalistic and ideological impetus behind such work. Throughout much of the history of folklore, however, more materials, or 'genres', are encompassed within the field of folkloristics (Figure 1).

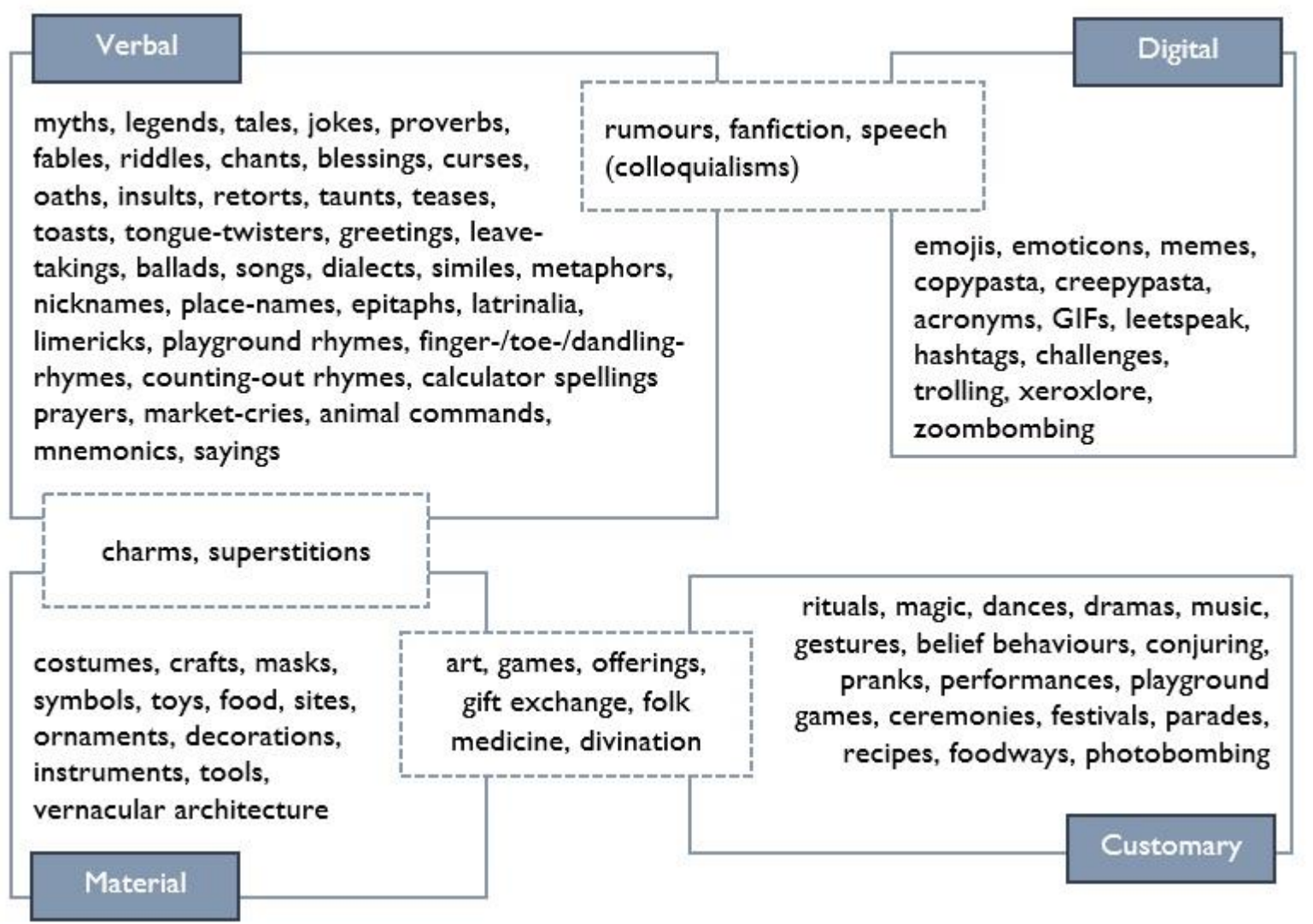

Figure 1. Some folklore genres. (Image by the Author) 
Folklore studies have, however, moved beyond genres and 'collection' to emphasize expressive communication, text (in the figurative sense) and context, in an integrated approach to the study of vernacular culture. Genres do, however, serve as a good starting-point to give those unfamiliar with the discipline the elements that might constitute folkloric practice, just as we might say that an archaeologist might study bones, pottery, and inscriptions - but it is what these can tell us about individuals and societies in context that we are more concerned with.

Considering the various genres of folklore, the 'folk' can thus be just as broad - not merely the socalled 'peasants' that antiquarians originally sought to study, or, indeed, that the unfamiliar academic might think of today. As seen in the definition above, the 'folk' under study can be defined by a specific commonality, and these groups are often referred to as the 'social base' of folklore. Various social groups or publics are thus central to the study of folklore. It is easy to see how, even on this basic level, folklore is relevant to the study or enactment of public archaeology, since many of the materials or genres of folklore overlap with archaeological materials, sources, or manner of engaging with archaeological remains, and the 'folk', social base, or otherwise 'public' are central to the field. It is argued here that without a thorough understanding of our publics, which is gained from an understanding of, among other things, their folklore, and its study, we can only have incomplete engagements with them.

\section{Folklore and the history of archaeology}

I have dealt in detail elsewhere with the intertwined historical trajectories of archaeology and folklore (Paphitis, 2013), illustrating their common aims, theories, approaches, and (mis)uses through time. I will summarize here those developments in archaeological thought most pertinent to how antiquarians and archaeologists interacted with the public, and how folklore played a role (or not) in this.

\section{Emergence}

Both archaeology and folklore observe part of their roots to be in the antiquarian phenomenon that emerged in early modern Europe (see Dorson, 1968; Trigger, 2006). This distinct approach to historiography is characterized by its material turn in combination with explorative and comparative approaches to local vernacular culture. The revaluation of history and history-writing occurring at a point of social, political, and religious reform is no accident, and the public or folk played an integral role in conceptualizing the past and imagining the newly formed nation that was built upon it. Antiquarians engaged in 'walking tours', visiting counties, countries, or regions and physically or figuratively 'collected' antiquities. These 'popular antiquities', as they came to be known in Britain, comprised archaeological and architectural remains and features, aspects of rural work, customs, and traditions of the peasantry, including festivals, narratives, and proverbs. In this way, antiquarianism saw the public and their vernacular culture as a source of information about the past, projecting what they collected on to how the 'less-civilized' societies of the past thought and behaved. In the antiquarian agenda, therefore, the folk provided information that legitimized claims to land or continuity of a people through historical inference or direct historical approach. The public were used to support a particular interpretive political agenda and were not considered to have been aware of the wider significance of their own folklore.

The idea of peasants as 'stores of tradition' was maintained and expanded by John Aubrey (1626-97), who saw popular antiquities as part of 'natural history' (Dorson, 1968: 5). Aubrey introduced the concept of 'comparative antiquity' (Schnapp, 1993: 192; Trigger, 2006: 106), constructing a method comparing type and chronology in order to understand prehistoric and historic objects and monuments as part of a 'scientific antiquarianism'. This approach to antiquities, and the view that they could be placed within a structure of 'natural development', set views of ancient remains and their associated tales and customs within a cultural evolutionary framework, which continued and developed into the nineteenth century. John Lubbock (Lord Avebury) argued that, just as elephants can provide information on extinct mammoths, 'modern primitive societies can shed light on the behaviour of 
prehistoric human beings' (Trigger, 2006: 171; see Lubbock, 1865; 1870) by way of direct analogy. Likewise, Edward Burnett Tylor's $(1865 ; 1871)$ theory of mythology in the anthropological school of folklore saw folklore as the 'tattered remnants of savage myths' preserved by peasants (Dorson, 1968: 191). Such myths fit into an evolutionary system, where the earliest were animistic nature myths constructed by savages, and higher levels of sophistication were represented by philosophic and historic myths explaining the mysteries of the universe.

By this point in the nineteenth century, archaeology and folklore had become distinct disciplines, with the first Chair in Archaeology having been established in Leiden in 1818. In the UK, The Folk-Lore Society (later The Folklore Society) was formed in 1878 after correspondence from Eliza Gutch in Notes \& Queries suggesting the formation of such a society, becoming the first in the world dedicated to the subject (Simpson \& Roud, 2000: 128). In the first issue of the Society's journal, The Folk-Lore Record (later Folklore), it detailed its aims as being 'the preservation and publication of Popular Traditions, Legendary Ballads, Local Proverbial Sayings, Superstitions and Old Customs (British and foreign) and all subjects related to them' (The Folk-Lore Society, 1878: viii). Meanwhile, archaeology had moved away from the garnering of information about the past through the modern folk, focusing instead on material culture and, where available, ancient literature. Yet both archaeology and folklore maintained a good relationship, with common aims, theoretical approaches, and, ultimately, uses.

Scholars in the nineteenth century eventually rejected cultural evolutionism for diffusionist models, which equally considered the peasant classes to represent stores of ancient tradition, but instead the sources and variations of such traditions were the result of migration, rather than independent development. A dominant view in archaeological and folkloristic approaches in Britain took the view that peoples from a superior civilization migrated, and it was by this mechanism that various cultural indicators, such as myths and material culture, expressed similarities and variations (see, for example, Müller, 1865; G. E. Smith, 1911). Ruling classes and particular nations represented the purest descendants of these ancestors, thus justifying the control and colonization of supposedly lesser peoples, and legitimation over land (Trigger, 1984). The service these scholarly views did for romantic nationalism going into the twentieth century is well rehearsed, and there is no room to explore this further here (see Trigger, 1984; Arnold, 1990; 2006; Paphitis, 2013, for example). Here we see national narratives told by experts to serve overt political agendas, where the imagined folk of the past and present (Anderson, 2006) are indirectly party to the formation of a national past through their appropriation as 'knowledge-bearers' and 'pure descendants'. The traditions of the peasantry were appropriated by scholars in constructing national narratives, and by the upper classes to demonstrate their natural relationship with the land.

\section{Estrangement}

The mid-twentieth century saw the distancing of archaeology and folklore from their approaches prior to the Second World War, and also from each other. Expert archaeologists trained in scientific approaches focused on material culture, empirical observation, and scientific analyses, eliminating the use of oral and literary data. Folklorists such as Richard Dorson $(1950 ; 1959 ; 1973)$ in the US introduced the concept of boundary-work, where folklore was the domain of academically trained folklorists. Amateurs, popularizers, the mass media, and academic interlopers were excluded from engaging in folklore studies in order to avoid the reproduction of so-called 'fakelore'. In general, folklore markedly avoided material culture analysis. Archaeology and folklore, however, were not so different in their theoretical approaches, both looking to processual, structural, and functional explanations.

The results of both disciplines' approaches to the public were also similar. Within archaeology, the public were no longer sources of information and were instead there to be educated about the past, yet the highly scientific language used by archaeologists prevented the public from fully understanding and engaging with the work of archaeologists (see Hawkes, 1968 for a contemporary criticism of this). The boundary-work of folklore not only led to the exclusion of non-academic folklorists, but further implied that tradition-bearers and practitioners could not consciously analyse their own traditions, and were therefore 'outside' of folklore's boundary (Briggs, 2008: 99). Despite both disciplines being concerned with the political appropriation that culminated in the atrocities of the first half of the twentieth century, 
neither seemed aware of the socio-political implications of their work. This is aptly illustrated by Dorson's (1962: 163) claim that 'the democracies of course do not use folklore for propaganda, but for knowledge and insight'. ${ }^{3}$ As Noyes (2012: 21) comments on folklore studies of the 1960s and 1970s, 'functionalist social theory turned nationalist ideology into science by positing that the world was naturally divided into organic self-containing collectives'. This could equally be applied to archaeology: Leone (1973: 129) argued that archaeological places served as 'the empirical substantiation of nationalist mythology' (also Tilley, 1989: 113-14; Shanks \& Tilley, 1992: 68-100), masquerading as vehicles of education.

It is interesting to note that the predominantly limited engagement with the public within archaeology at this time mirrors its limited engagement with folklore. We can take this observation further to consider that, without openness to folklore in archaeology, understanding of and engagement with the public suffers, and so a real rapprochement between archaeology and folklore can have exciting prospects for public engagement.

There were, of course, exceptions to this disengagement. Folklorist Henry Glassie $(1969 ; 1975)$ undertook extensive studies in folk material culture and vernacular architecture in the eastern United States, whilst archaeologist James Deetz $(1977$; 1988) explored oral traditions in his investigations of plantations. Grinsell (1976a) completed his Folklore of Archaeological Sites in Britain and continued his collaborative works in this area (Grinsell 1976b) under the auspices of the Prehistoric Society and the Folklore Society. Most famously, Leslie Alcock $(1969 ; 1971 ; 1972)$ undertook his archaeological investigations of Cadbury Castle, Somerset (see Paphitis, 2013; 2014), in which part of the aims of the project was to assess if this could have been the site of 'Arthur's Camelot', asking, 'what historical reality might be behind such folk-lore [...]?' (Alcock, 1972: 12).

This project relied heavily on public and private donations, which it successfully accrued, and it can be argued that it is unlikely to have achieved the funds it did without the Arthur connection. The folklore of the site thus prompted public enthusiasm for archaeology, and, although some archaeologists may not look favourably on this approach, doubtless much work beyond the question of Arthur was carried out at, and knowledge gained about, the site as a result of it, potentially instigating wider public interest in archaeology generally (see Paphitis, 2014: 196-243). The main interest in the folklore in this project, however, was to assess its empirical substantiation, rather than in understanding its cultural relevance.

The public archaeology dimension of the Cadbury-Camelot project went beyond eliciting interest for the purpose of funding the project. Although not noted by the Camelot Research Committee, the political aspect of the project cannot be over-looked. In a post-war Britain, the notion of a 'native' British hero defending his land against Saxon invaders resonated with the defeat of Germany by Britain and its allies, and a distancing from the country's Germanic heritage was in order (see Higham, 2002: 27-28). This example illustrates the need to consider the historic interactions, in their varied forms, between archaeology and folklore, since they give us an insight into public interests in sites and the past, and the significance of and motivations for research.

\section{Reconciliation?}

The development of interpretive and contextual archaeology and folklore in the 1980s and beyond came out of researchers' dissatisfaction with the direction of their respective disciplines. Both came to critique the systemic and deterministic approaches of the previous decades, reorienting their approaches towards social theory, and attempted to resituate their disciplines within the contexts in which they were practised. This included reinstating dialogues with the public. Within archaeology, this would manifest in the recognition of multiple voices in both the past and present, with the examination of agency in the past on the one hand and interactions with the public in the present on the other. Inclusive and participatory models came to be used alongside education models espoused in scientific archaeologies (see Holtorf, 2007).

Multivocality squared the interpretive problem of contextualization, particularity, and meaning-making with the espousal for an increased recognition that the public viewed and encountered the past and its 
remains in various ways. However, I argue that the multivocal agenda in archaeology has not sustained earlier efforts to incorporate a plethora of voices as a matter of course within archaeological investigations, ${ }^{4}$ and a way we can reinvigorate this is, in part, through a better understanding of folklore, which not only helps us understand our 'publics', but their ideas, processes, and ways of meaningmaking.

These reflexive, holistic, and interpretive developments in archaeology and folk-lore led to a degree of 'rapprochement' between the two disciplines (after Burke, 2004: 135-37), leading to various reconsiderations of folklore in archaeological research, with a significant increase in research and publications, as seen in volumes such as Gazin-Schwartz and Holtorf's Archaeology and Folklore (1999; also Wallis \& Lymer, 2001b; Falk \& Kyritz, 2008; see Paphitis, 2014: 27-30 for a summary of the various interactions between archaeology and folklore).

Contemporary engagements between the public and archaeology/archaeologists have been the main focus of public archaeology. However, direct engagement with sites and landscapes by various groups in the past is also discernible in historic folklore collections (see further Gunnell, 2010) and the histories of archaeology and folklore, as we have seen here. Through the examination of historic folklore, we are able to both observe and understand these interactions, demonstrating the reciprocal influence of social groups on archaeological sites, and vice versa, including how the past is used by groups in the past through folklore. Public archaeology need not be restricted to the present, but can be undertaken in what might be called a retrospective public archaeology through the examination of historic folklore, which can contribute to an understanding of how the public engage with such sites today — including why folklore is perpetuated about certain places. An analysis of the historic folklore of archaeological sites, or the historic/archaeological motifs found in folk custom, can therefore serve as a form of historic public archaeology, since this gives us an insight into how various social groups through time viewed, interacted with, and used archaeological remains, or employed the past in contemporary folklore and wider invention of tradition (Hobsbawm \& Ranger, 1983). However, folklore is not merely restricted to historic collections: it is a vibrant and contemporary cultural phenomenon that is constantly being produced, altered, or abandoned, according to contemporary engagements with social, cultural, political, and other developments. Such folklore deserves just as much, or more, attention as historic folklore, and can be public-archaeologically explored in ethnographic and multivocal frameworks.

\section{Public multivocality and ethnographic archaeology}

Multivocal approaches in archaeology are open to the active participation in the dis-course about the archaeological process by different groups of people (Hodder, 1997: 694) in order to ascertain the various views of the past and its remains as held by these people. Proponents have claimed that such approaches are 'ethically conscious', particularly in giving indigenous and post-colonial groups a voice (Hodder, 2003: 56). The First World Archaeological Congress (WAC) in 1986 was a benchmark in enhancing collaboration between archaeologists and indigenous peoples (Ucko, 1987), and this engagement was boosted by the advocacy for a multivocal approach to archaeology that respected and considered the views held by such groups. Engaging with indigenous and descendant communities is now a widespread practice in the pre-colonial archaeologies in, for example, the Americas and Oceania (e.g. Colwell-Chanthaphonh \& Ferguson, 2008; also Marshall, 2002). Not all archaeologists, of course, advocate indigenous engagement with archaeological research (cf. R. J. Mason, 2000), but, on the whole, many are receptive to this kind of interaction. Multivocal approaches are obviously not restricted to engaging with indigenous groups, but with any who have any claim or interest in the past and its remains. Yet, as Harald Fredheim (2020) contends, archaeology is far from being truly 'open' and decolonized, despite an explosion in participatory approaches and the mobilization of digital technologies. Whilst not solving this problem, folklore can assist in advancing the aim of a more open archaeology through its methods, materials, and interpretations.

With whatever groups archaeologists are working, ethnographic methods have been recognized as having the potential to enhance how archaeologists engage with, and understand, the public. As a discipline grounded in ethnographic approaches, folklore offers potential frameworks for engaging with 
the public through the narratives and customs that connect people to places, or understanding how people conceptualize the past through such folklore. ${ }^{5}$ Within folklore ethnographies, emphasis is often placed on reciprocal ethnographies, where interpretations are checked and discussed with participants. We can in turn interpret such ethno-graphic data through a reconsideration of multivocality as essential, rather than superfluous, to investigations of archaeological places. Exploring the concept of multivocality in the context of Fyodor Dostoevsky's novels, Mikhail Bakhtin (1984: 6) describes the polyphonic narration within these novels as the presentation of independent voices, each 'with equal rights and each with its own world'. Such voices may combine in the narration of an event, but are not merged. Individuals are thus 'autonomous subjects' rather than objects, ultimately leading to 'the profound organic cohesion, consistency and wholeness of Dostoevsky's poetics'. We might take a leaf out of Bakhtin's consideration of polyphony in rethinking the practical application and interpretation of multivocality in archaeological research, and we can do so through the practical engagement with folklore.

Advocating a reflexive, multivocal approach to archaeology has led to the development of a specific field within public archaeology, which in recent years has come to be called 'ethnographic archaeology' (Edgeworth, 2010: 53). Ethnographic archaeology is a method for examining people's varied contemporary engagements with the past. Here, ethnographic methods are incorporated into archaeological investigations to examine the epistemological, social, and ethical nature of archaeological practice (Edgeworth, 2003; 2006), or, more commonly, 'in order to explore the contemporary relevance and meaning of the material past for diverse publics, the politics of archaeological practice, and the claims and contestations involving material traces and landscapes' (Hamilakis \& Anagnostopoulos, 2009: 66; also Castañeda \& Matthews, 2008: 1). Ethnographic archaeology thus not only gives voice to multiple interpretations, but also to multiple interactions that do not leave material traces (Castañeda \& Matthews, 2008: 2). It is in this way that we may practically engage and understand the folklore of archaeological remains. The ongoing engagements between people and archaeological sites are a worthy field of study, and perhaps more pertinent to contemporary society in shaping their current and future worlds.

Whilst much ethnographic archaeology is conducted as part of wider archaeological research projects (typically excavation), researchers can and should undertake ethnographic archaeology as a research project in its own right, particularly in the specific exploration of folklore, since people reflect on archaeology/the past outside of the presence of a traditional archaeological research project. Such investigations need not be restricted to contemporary engagements, but may also be constructed through sources such as folklore collections in a historical perspective. Through such ethnographies, we gain an insight into how the public have not only contributed to, but actively shaped, a site's or artefact's lifehistory through folklore. On the other side of the same coin, we further gain the opportunity to understand the agential influences of material culture and other non-human agents on individuals and groups (Olsen, 2010) as represented in the creation and reproduction of folklore.

As well as the construction of site biographies, archaeologists intending to undertake investigations of sites with a public archaeology dimension would also benefit from an approach incorporating folklore research as part of desk-based research prior to archaeological investigation. This might not only add to archaeologists' own understanding of the site, but also pre-empts questions from the public pertaining to folklore related to it (cf. Matsuda, 2009). Researching local folklore further shows sensitivity to local knowledge and custom, which are often closely linked to how people identify with places and the past. Such preparation further allows for the ability to provide information and interpretation of the folklore and its connection to particular sites if and when approached by the public. As a result, archaeologists can encourage reflexive thinking about a site through the discussion of varied interpretations in archaeology and folklore with the public.

We might here return to Bakhtin's approach to polyphony. Just as Dostoevsky's novels are, as Bakhtin (1984: 18) contends, 'a whole formed by the interaction of several consciousnesses', rather than a monolithic whole formed by the merging of consciousnesses, so too can we consider the myriad of voices about an archaeological site. This not only gives us a perspective through which to approach 
multi-vocality in archaeology, but also a means by which we can understand the role and mechanism of the (re)production of folklore in relation to place. The interpretive approach to varied narratives as meaningful and co-occurring can be seen as analogous with Bakhtin's (1984: 43) consideration that the analysis of a single view-point in Dostoevsky's novels from a 'real-life' perspective impoverishes both that viewpoint and the overall text. The same can be said of folklore and its use in archaeological research, where the assessment of a tale's historicity overlooks and diminishes the meaningful nature of the narrative, and its dismissal deprives the site of its rich, vibrant history and contemporary relevance. In this way, the varied voices connected with archaeological sites is not seen here, as Stroulia and Sutton (2009) do, as 'landscape dissonance' — a term which creates more schisms between archaeologists and the public — but a synchronized whole. ${ }^{6}$

Folklore can thus form part of the dialogue between archaeologists and the public, through the exchange of narratives about place and landscape. Such dialogues both aid archaeologists in understanding what narratives the public have heard and tell, and provides opportunities to discuss these and archaeological results together, in what may be termed a dialogical public archaeology. In considering this in a practical way, responses to surveys (Paphitis, 2014) have shown that, despite the fabulous nature of some folk narratives about a popular folk hero, and their anachronisms with the archaeology of the place about which these tales are told, the public accept the variances in archaeological and folk narratives as part of the depth of the site. The narratives, according to members of the public surveyed, 'add another layer of interest' to the site, giving the place 'atmosphere', stating that 'it's nice to have some romance!' The archaeology can be and is deemed to be just as exciting as folk narratives: its significance is not diminished, nor its acceptance by the public compromised. In no cases of c. 500 individuals surveyed was the archaeological narrative rejected in favour of the folkloric one as 'true'. The active discussion of varied narratives at archaeological sites can help explore the diverse engagements social groups have had with that particular place, and assist in involving those interested in archaeology or the site. Through this, we can appreciate that various ways of seeing and being in the world are extant in various contemporary societies, and are worthy of study through a practically and interpretively useful inclusion of folklore.

\section{Folklore, historical consciousness, and the archaeological imagination}

Folklore is sometimes (though not exclusively) created and enacted with some kind of reference to the past and its remains. Because of their frequent concern with the past, legends can be seen to reflect the historical consciousness of a given society (Gunnell, 2008: 16; Siikala, 2008: 39, 48). Historical consciousness is a particular group's views on 'the shape of time and the relationship of events in the past, present and future' (Stewart, 2012: 2), where the ideals of the best future, based on ideologies of the present, are often inverted as a mythical past (Knuuttila, 2003: 152; see also Barczewski, 2000). Charles Stewart (2012: 3) describes the study of historical consciousness as an 'anthropology/ethnography of history', as it is expressly concerned with how individuals and societies construct and relate to the past in the present in relation to their own motivations, systems of belief, organization, identity, and so on. Historical consciousness is not a 'false' conscious-ness, but a signification of how groups relate to the world (Barthes, 1973), that can be expressed through various means, including narratives and material culture.

Concerns with alternate notions of historicity as expressed by folk custom were considered in Vladimir Propp's 1928 structuralist treatise Morphology of the Folktale, where the concept of history

lies in the people's expression of its historical self-awareness and in its attitude towards past events, persons and circumstances rather than in the ... correct depiction of historical persons or relation of events considered real. Historical significance is an ideological phenomenon. (Propp, 1968 [1928]: 51)

Such conceptions may be activated in the present by means of affective images and symbols, resulting in, for example, the production of folk narratives which may draw on remnants of the past rearticulated in the present. Current interests in historical consciousness are primarily derived from a rejection of 
Western historical notions of linear chronology and an acknowledgement of multiple, often conflicting, views of the past. A number of studies of the perception of the past and how it pervades the present in non-Western societies such as Columbia (Taussig, 1984), Madagascar (Lambeck, 2002) and the Sudan (Larsen, 1998) have been conducted, from which Stewart (2012: 7) observes that people may produce histories and approaches to history that differ from Western historiography, the documentation of evidence, and its objective scrutiny. As Stefan Brink (2013: 33) observes, 'in many cultures there is no dividing line between mythology and history' (see also Nyberg, et al., 1985). It is therefore futile to separate the two in a people's understanding and creation of the past, from which it constructs its present.

Alternate views of history are not solely restricted to 'non-Western' societies, but can also be produced by social groups around the world. As Woolf (1988) has demonstrated, the use and decline of 'the common voice' by scholars does not mean that histories were not created by 'the people', but that they were not incorporated into official historiographies, which ignored and overshadowed these narratives, and were themselves politically and ideologically motivated (see L. Smith, 2006). Discussing within a European folklore context, Niedermüller (1999: 251) states that, 'folk culture does not refer [...] to historically existing reality, but much more to its politically motivated image'. Thus, the study of the historical vera-city of folk narratives is not what is important, but the meanings these tales have to those who reproduce them in the present through their representation of the past (Tolkien, 1947: 128).

The political image formed from conceptualizations of the past, present, and future as represented by narratives referring to specific places in the landscape has been termed by some writers the 'mythscape' (Bell, 2003; Knuuttila, 2003). Archaeological and other landscape features, as physical manifestations of the past in the present, are used to substantiate the narrative and message related in a form of 'mental bridging' (Utz, 2006: 27). Jacqueline Simpson (2008) presents the concept of the ghost story as a prime example of the pervasion of the past in the present, as ghosts are not only by their nature remnants of the past, but also haunt places that survive from the past, such as houses, monuments, and ancient sites. Their presence at a particular place (or the creation of a place through the presence of a ghost) both humanizes the past (and place) and connects it to direct experience in the present. Through an examination of the place of English ghost stories, Simpson (2008: 33) concludes that such narratives are 'evidence of a community which identifies itself by reference to history, even if that history is bogus' (emphasis added). These historical links, Anttonen (2005: 106) argues, are not whimsical distractions, but are active and goal-directed, even if seemingly absurd and knowingly spurious. Such creation of historical narratives demonstrates that 'history' is a form of social knowledge, not solely the prerogative of the historian (Samuel, 1994: 8), which can be accessed through folklore. The construction of the past through legends and folktales therefore not only reflect the historical consciousness of a given society, but also the real experiences of their own local topography (Dégh, 1996: 41).

The presence of the past in the construction of public identities in the present is thus well illustrated by folklore. Through folklore, we see the process and results of the archaeological imagination in action, where experiences of archaeological sites result in contextually bound narratives, and, in the other direction, the construction of local and national narratives point to remnants of the past. The consideration of archaeological imagination and representation is here taken further than how such topics have been and are often approached, which focus mostly on film, literature, fine arts, music, and gaming. Archaeological representation can go beyond 'high' culture in medieval, post-medieval, and modern periods, as well as in contemporary mass/popular culture; it can also be perceived in the vernacular through folklore, which is an influence on, and influenced by, these media. The crossovers between folklore and archaeology have found extensive and distinctive representation in film and literature in particular, in the genres of folk horror, fantasy, and the gothic. These popular culture products may be studied in reverse, exploring their use of folklore to represent the past, and how these feed into contemporary concerns or scholarly thinking. In this way, archaeological sites and landscapes form part of broader literary or film heritage through folklore, and the boundaries of experiences of place are widened or dissolved (see Paphitis, 2014: 293-308). 
Folk narratives and other genres are created, reproduced, and recontextualized for a particular purpose according to specific contexts, and are thus meaningful to the groups to whom that folklore belongs. When such contextual analysis of folklore is undertaken in relation to archaeological sites, whether employing historical folklore collections or contemporary ethnographies, this can not only reveal interactions between people and archaeology, but aid in interpreting their meaning and significance to such groups. The study of folklore can thus be seen as a form of interpretive public archaeology, where we go beyond what the public think or how they engage with the past to why and to what end. This not only gives archaeologists a clearer understanding of meaning and motivation, but also does justice to the varied engagements the public has with the past and what it means to their present and future.

\section{Folklore and the managed past}

The 'education model' set out by archaeologists in the 1960s and 1970s gave us the foundation for Archaeological Heritage Management (AHM) or CRM practices. There is no need to summarize this approach and its criticisms here (see Merriman, 2002; 2004; Holtorf, 2007), but I will briefly set out the limitations of these models in communicating and understanding folklore that is closely connected to archaeological sites in the UK, and how they intentionally overlook and demean folklore that was or is actively reproduced through encounters with archaeology.

Earlier approaches in AHM and its associated models can be seen to take a limited view of how the past should be approached and presented, and does not address the interests of the public, other than what it believes them to be. Whilst this has changed across many regions globally in recent years to more consciously consider the varied interests and backgrounds of the public, earlier approaches have left a legacy in the UK of (perhaps unintentionally) overlooking other ways of knowing and engaging with places. This includes, for example, folk narratives told about archaeological sites, or other practised customs, which, alongside archaeological interpretation, constitute the history and heritage of a place, demonstrating ongoing and meaningful engagement, and connecting the past, present, and future.

This is what led to Grinsell's (1980) concern for the loss of (the knowledge of) folklore due to the promotion of archaeological interpretation. It does not mean, obviously, that folklore concerning archaeological sites is no longer reproduced, but the full history and heritage of place is not presented to the public as the folklore is not believed to 'fit into' the official archaeological narrative (i.e. it is not 'true'). There are, of course, some exceptions to this, especially where the folklore can be seen to attract funds or visitors (Simpson, 2008). Ghost stories, for example, are one category of folklore that are not so desperately dismissed by heritage managers (e.g. English Heritage's Haunted Heritage [J. Mason, 1999]), since they do not typically comprise narratives that 'contest' archaeological interpretation indeed, they can be seen to potentially help substantiate it (see also Cowdell, 2014). More recently, of course, heritage managers have been keen to incorporate participatory approaches in order to widen 'access' to heritage or get the public to contribute after citizen science models (see Carletti, 2016). Yet many of these are contributory or collaborative, rarely initiated by communities, so there is still a somewhat 'top-down' approach, where heritage managers 'open up' participation according to an institutional perspective. Thus, whilst Johnston and Marwood (2017) suggest such an approach can assist in, for example, social justice, blind spots and tensions remain (see Kaufman, 2009).

\section{'Championing England's Heritage'?}

An example of the inconsistent, selective approach to folklore within UK national heritage management can be seen in a brief study of Historic England's site listings. ${ }^{7}$ A keyword search for 'folklore' within the listings yields 77 results, out of a catalogue of 399,543. These were mostly holy wells: 56 out of 77 (73\%). All holy wells listed are given the same general description detailing their significance as a (Catholic) Christian monument, which persisted during the Reformation through local folklore, their possible origins in pre-Christian tradition, and their potential and consistent physical features. Because of this general description, far fewer listed holy wells have folklore specific to them described on the website than the initial number of hits would lead one to believe, and much fewer still where the folklore of the site was part of the reason for listing (all were predominantly listed due to their 'religious', 'archaeological', and 'environmental' significance). The remaining twenty-one sites comprised six 
standing/wayside crosses, three standing stones, two chapels, two barrows and one boundary marker, hillfort, cross-dyke, bowling green, statue, maze, toll house, and settlement (which included a holy well).

A key word search for 'legend' brings up an initially surprising 499 hits, but this again is misleading, as most of these are due to the use of the word 'legend' to mean 'inscription' or 'decorative device'. After removing these, and removing those sites which are described as being decorated with 'the legend of' something (such as churches being decorated with the legend of the saint to whom it was dedicated), sixty-four listed sites have a reference to a legend directly connected with them, often used to explain their onomastic origins. The reference to these legends and folklore are preceded or succeeded by the words 'colourfully', 'unsubstantiated', 'unfounded', and 'certainly not supported'. Whilst it can be seen that this is to make clear the archaeologically and historically founded narratives of the site, the language used to dismiss and denigrate such folklore is unnecessary and can be insulting to those reproducers of folklore who identify with the site through it and derive meaning from it. The folklore may be presented in such a way as to indicate that it is precisely that: folklore, and include a brief description explaining that, whilst not necessarily 'historically accurate', does reflect the changing view and importance of the site over many years, and is nevertheless an important aspect of the heritage of the site. That Historic England does not consider the folklore in this way indicates a lack of interest in the broadest sense of the 'history' of the listed site and the heritage elicited from such histories, whilst reinforcing the AHM approach to 'educating' the public.

Looking more closely at, for example, Hilary Orange's (2006; Orange \& Laviolette, 2010) interpretation of the 'conflicting' narratives of Tintagel, which is rich in the folklore of King Arthur (and listed by English Heritage as such), we can see how a concurrent interpretive presentation of folklore and archaeology may be beneficial to a site and heighten visitor experience of it. Orange's work considered the presentation of the archaeological and folkloric interpretations of Tintagel within the village (such as the Tourist Information point and shop) and on-site by English Heritage. The village shop and English Heritage's marketing material promote the Arthur legend to tourists and would-be tourists, in contrast to the 'debunking' of Arthur narratives by English Heritage in their introductory video on-site, which in turn appears to conflict with on-site information panels which declare that, in spite of the lack of evidence, the atmosphere of Tintagel lends itself to the romantic nature of the legends. Such conflicts in presentation have, Orange found through on-site surveys, led to a confusion over Tintagel's history and the place of Arthur narratives within that history, leading in many instances to an 'unsatisfactory heritage experience' (Orange, 2006; Orange \& Laviolette, 2010).

Whilst, on the surface, this 'failure' in the presentation of Tintagel may suggest that the concurrent presentation of archaeology and folklore on-site only confuses visitors and inhibits their ability to learn about the archaeology of a site, it can be seen that the failed visitor experience of Tintagel is due to the lack of presentation of the meaning and interpretation of the folklore: how and why it came about, how it is connected to the site, and why, although there is no archaeological evidence to support its historical veracity, the folklore persists. The presentation and contextualization of the invention and perpetuation of this tradition is no less interesting to visitors, or significant to the site, and simultaneously aids in English Heritage's quest to present the 'archaeologically accurate' interpretation of Tintagel, whilst including the folklore of Arthur that many visitors know about and expect to encounter. Side-stepping the folklore does not work here. It is not a question of 'de-bunking' folk narratives in favour of archaeological ones, but taking a more critical approach to how the myriad of narratives about place intertwine and are presented.

Recently, The National Trust launched a call for the public to contribute legends and superstitions 'amid growing interest in the subject' (National Trust, 2019) having established temporary folklore-related trails and activities in and around their properties and published A Treasury of British Folklore (Chainey, 2018). ${ }^{8}$ The publication was essentially an elaborate list of tales and customs, which presented some interesting tales but with a lack of in-depth exploration or interpretation of the folklore. On examining the call, their activities, and the Treasury, we are left wondering who they are trying to engage here. Ultimately, it is those who already engage with the Trust. What is the Trust going to do 
with these public submissions? According to the website, nothing much more than 'record' them so they are not 'lost'. Such naivety in engaging with both folklore and the public can be seen to stem from an ignorance of not only the folklore itself but also folklore studies.

In the last few years, the American Folklore Society (AFS) established a Working Group on Folklore in Historic Preservation Policy to more prominently position folklorists and folklore methodologies within historic preservation in the US. Whilst folklorists have played a role to some extent in US heritage management since 1980, it has become clear more recently that an increased involvement of folklorists can help tackle contemporary social issues in this area (see Sommers, 2019). ${ }^{9}$ In some European states, folklore is embedded into protective antiquities legislation, even if the folklore is not attached to an 'archaeological' site. ${ }^{10}$ I would suggest that, if UK heritage managers really do want to increase participation of diverse communities, and apply heritage to contemporary challenges, they consider this call for interaction made by the AFS, working in collaboration with archaeologists, folklorists, and diverse communities.

Within local and national heritage management in the UK, folklore has been treated as a separate, often less significant, form of heritage, or excluded entirely from the presentation of places with strong archaeological and folkloric heritage. Yet there is not only a public interest in folklore, but also a deeper engagement with places through it. There appears to be a sea-change in UK heritage management, with a view to incorporating a range of views and forms of heritage, including folklore - which we as public archaeologists are well equipped to contribute to through research and participation. It seems the answer here, then, is to rigorously and harmoniously (with participants) account for folklore in research and public institutions, considering the methodologies of retrospective, dialogic, and interpretive public archaeology outlined above.

\section{Conclusion}

This paper was concerned with how public archaeologists in the United Kingdom might better expand their approaches through incorporating folklore. In the UK, folklore has not enjoyed the scholarly status that it has in the rest of Europe and beyond, and perhaps this is a factor in the lack of explicit engagement with it within public archaeology (and archaeology generally). The inclusion of folklore in public archaeological research is here not seen as a way of gaining an 'alternative' insight into perceptions of archaeological remains, but a way for archaeologists to understand how places are experienced, and of their meanings to and appropriation by various groups through time. This is a way in which archaeologists can examine the social, cultural, and political agendas in the interpretation of the past and in the present, and practically engage in multivocality in order to produce archaeological ethnographies, without limiting themselves to traditional archaeological materials and publications. We can see that the wider public do not limit themselves in this way when learning about or otherwise experiencing the past, or constructing heritages in the present, thus there is no reason for archaeologists to do so.

Folklore can help eke out and develop the multiple strands of public archaeology as a field of research. Historic folklore, and the history if the discipline itself, can give us insights into how people in the past engaged with archaeological sites, constructed and imagined the past, and how such views and archaeological sites were exploited in local and national narratives. This retrospective public archaeology helps us understand legacies of the discipline of archaeology and of folklore today, which not only affects how we work with the public, but also how we consciously and unconsciously construct knowledge about the past in the present. Wariness of previous pitfalls in the combination of archaeology and folklore may, in the UK, have led to a distrust of the latter by archaeologists, which can be seen to have had an impact on the extent to which we engage with the public through folklore. However, by developing a dialogic public archaeology, we can open up conversations with the public through folklore, whether it is in discovering more about a particular site's history and significance, or in comprehending how diverse communities conceptualize and value the past. Through folklore-oriented dialogues, public archaeologists might better understand participants with whom they work, and audiences they seek to engage. As a result, we may develop new and exciting interpretive public 
archaeologies that gain a deeper, meaningful appreciation of the multiple engagements people have with the past and places in the present.

Folklore serves as an ethnographic, outreach, community, and data-gathering exercise. The employment and examination of folklore in archaeological research, and any other multivocal practices for that matter, do not diminish or belittle the role of the archaeological 'expert', which is often feared to be the case. Indeed, the expert is essential for the rigorous assessment and interpretation of these view-points, as well as for traditional archaeological interpretations the public come to expect, and that many are seen to enjoy learning about and reflecting on, in addition to and as a result of their own experiences, which may be through folklore. As such, it is not argued here that the exploration of multiple voices should override the interpretation of sites and other archaeological remains by expert archaeologists, but that they are part of that coherent whole, understanding the place of such remains within specific social, cultural, and historical contexts in the imagination of various publics. Our understanding of, and engagement with, our brilliantly diverse communities in the UK might be helped through this potentially fruitful collaboration.

\title{
Acknowledgements
}

Part of this work is derived from my doctoral research, which was funded by the Arts and Humanities Research Council (AHRC) Doctoral Awards, and additional fieldwork grants from the UCL Graduate School and UCL Institute of Archaeology. Many thanks to Rodney Harrison for reading through the text, his suggestions and encouragements, and to the anonymous reviewers for their valuable comments.

\begin{abstract}
Notes
${ }^{1}$ Broadly conceived here as the field of archaeology 'concerned with any area of archaeological activity that interacted or had the potential to interact with the public' (Schadla-Hall, 1999: 147). This includes the collision of archaeology with politics, economy, ethics, creativity, and various other social and cultural areas, as well as conventional presentations of archaeology at sites, in museums, and in popular media. Yet folklore, as an arguably universal cultural phenomenon related to all these areas, has featured considerably little in public archaeology discourse, arising only by accident (Matsuda, 2009: 141-42, 242-56; 2010), viewed as an 'alternative interpretation' (Darvill, et al., 1999), or included in site biographies (e.g. Bender, 1993; 1998) where sites, rather than people and the inter-action between the two, are the focus.
\end{abstract}

${ }^{2}$ Although Thoms is often credited with coining the term, the compound folclär ('folk-lore') occurs in Anglo-Saxon manuscripts from the eighth, ninth, and tenth centuries, and an eleventh-century collection of Latin-Old English glosses (see Mazo, 1996). The word was distinct from bōclār ('book-lore' or 'book-learning'), where the former denoted common or popular knowledge and learning, whilst the latter was formal teaching or doctrine. It is possible, then, that Thoms revived a long-for-gotten word rather than invented it entirely.

${ }^{3}$ A rather odd statement for Dorson to make, given that he wrote emphatically and positively on the place of folklore in the service and representation of the state, ending his paper, 'American folklore will take its place alongside American literature, American politics, the history of American ideas, and other studies that illuminate the American mind' (1959: 212).

${ }^{4}$ This can not only be seen in the comparatively few multivocal approaches within archaeological research that are conducted as a matter of course, but also in archaeologists not practising what they preach. I once worked on an excavation of a site with popular contemporary and historical folklore that held regular open days/events for the public. When I asked the director of the excavation, who theoretically advocated multivocality, if there would be a stall discussing the folklore with the locals who were well versed in it, their response was firmly in the negative. 
${ }^{5}$ The training archaeologists have in engaging with the public appears to be negligible. Unless perhaps combined with anthropology, where working with living human subjects is part of anthropological training, archaeology degrees do not often include this element. Students may take courses detailing the theoretical and thematic aspects of public archaeology, and also on how to analyse and interpret data, but not, crucially, the bit in between. Folkloristics, on the other hand, is emphatic about working with people, and has developed thorough methods for doing so. Although this does not stop some from denigrating folklorists' work. When I informed a self-styled public archaeologist that I was about to go away on [folklore] fieldwork, they 'joked' that I would just be sitting in the pub chatting with the locals (which I might well have done, if my interest was in publore).

${ }^{6}$ This is not to imply that there are no conflicts and contestations by bringing narratives together in this way, but it is a method by which archaeologists can better recognize, address, and incorporate various narratives and their significance, forming a dialogue with others.

${ }^{7}$ See https://historicengland.org.uk/ (accessed 4 September 2017).

${ }^{8}$ One wonders how 'growing interest' was observed or measured here; perhaps it was more of a realization that people engage in folklore. The National Trust's call and activities focused on autumn, which it presumed to be a time in which people are particularly interested in folklore (because of Halloween).

${ }^{9}$ Folklore work is also part of the public sector in the US (see Baron \& Spitzer 2007), thus the crossover might be more easily facilitated here — but there are plenty of opportunities for heritage managers in the UK to engage with independent, academic, and Society-based folklorists.

${ }^{10}$ In Norway, for example, the Cultural Heritage Act (Kulturminneloven, 1978) protects, alongside ancient sites, "cultural monuments [...] including localities with which historical events, beliefs or traditions are associated' (my translation from Norwegian). Similarly, in Finland the Antiquities Act (Muinaismuistolaki, 1963) protects 'natural formations to which are attached old customs, legends or significant historical memories' (my translation from Swedish). Here, there is a recognition of the significance of place through folklore. Indeed, people visit sites (archaeological or not) because of their associated legends - a practice referred to by folklorists as 'legend-tripping' (see McNeill \& Tucker, 2018). These trips are mostly studied in relation to contemporary legends pertaining to hauntings, the supernatural or crazed murderers, particularly in the US. However, such trips may also be made because of an interest in a particular legend, not necessarily indicative of 'belief' in the legend, but for other reasons entirely, which we cannot gain a full picture of when folklore is dismissed. As such, we can broaden our conceptualizations of what constitutes a 'site' through folklore - this deserves closer consideration than can be given here.

\section{Bibliography}

Alcock, L. 1969. Excavations at South Cadbury Castle, 1968. The Antiquaries' Journal, 49(1): 30-40.

Alcock, L. 1971. Excavations at South Cadbury Castle, 1970. Summary Report. The Antiquaries' Journal, 51:1-7.

Alcock, L. 1972. 'By South Cadbury, is that Camelot...' Excavations at Cadbury Castle 1966-70. London: Thames and Hudson.

American Folklore Society, The. n.d. What is Folklore? [online] [accessed 4 February 2020]. Available at: http:// www.afsnet.org/?page=whatisfolklore.

Anderson, B. 2006. Imagined Communities: Reflections on the Origin and Spread of Nationalism, $2^{\text {nd }}$ rev. ed. London: Verso. 
Anttonen, P. J. 2005. Tradition Through Modernity: Postmodernism and the Nation-State in Folklore Scholarship. Helsinki: Finnish Literature Society.

Arnold, B. 1990. The Past as Propaganda: Totalitarian Archaeology in Nazi Germany. Antiquity, 64: $464-78$

Arnold, B. 2006. 'Arierdämmerung': Race and Archaeology in Nazi Germany. World Archaeology, 38(1): 8-31.

Bakhtin, M. M. 1984. Problems of Dostoevsky's Poetics, ed. and trans. C. Emerson. Minneapolis: University of Minnesota Press.

Barczewski, S. L. 2000. Myth and National Identity in Nineteenth-Century Britain: The Legends of King Arthur and Robin Hood. Oxford: Oxford University Press.

Baron, R. \& Spitzer, N. R. eds. 2007. Public Folklore. Jackson: University Press of Mississippi.

Barthes, R. 1973. Mythologies. London: Vintage.

Bell, D. S. A. 2003. Mythscapes: Memory, Mythology, and National Identity. British Journal of Sociology, 54(1): 63-81.

Bender, B. 1993. Stonehenge - Contested Landscapes (Medieval to Present-Day). In: B. Bender, ed. Landscape: Politics and Perspectives. Oxford: Berg, pp. 245-79.

Bender, B. 1998. Stonehenge - Making Space. Oxford: Berg.

Briggs, C. L. 2008. Disciplining Folkloristics. Journal of Folklore Research, 45(1): 91-105.

Brink, S. 2013. Myth and Ritual in Pre-Christian Scandinavian Landscape. In: S. Walaker Nordeide and S. Brink, eds. Sacred Sites and Holy Places: Exploring the Sacralization of Landscape through Time and Space. Turnhout: Brepols, pp. 33-51.

Burke, P. 2004. History and Folklore: A Historiographical Survey. Folklore, 115(2): 133-39.

Carletti, L. 2016. Participatory Heritage: Scaffolding Citizen Scholarship. International Information and Library Review, 48(3): 196-203.

Castañeda, Q. E. \& Matthews, C. N. 2008. Introduction: Ethnography and the Social Construction of Archaeology. In: Q. E. Castañeda and C. N. Matthews, eds. Ethnographic Archaeologies: Reflections on Stakeholders and Archaeological Practices. Lanham: AltaMira Press, pp. 1-23.

Chainey, D. D. 2018. A Treasury of British Folklore. London: The National Trust.

Colwell-Chanthaphonh, C. \& Ferguson, T. J. eds. 2008. Collaborations in Archaeological Practice: Engaging Descendant Communities. Walnut Creek: AltaMira Press.

Cowdell, P. 2014. Ghosts and their Relationship with the Age of a City. Folklore, 125(1): 80-91.

Darvill, T., Barker, K., Bender, B. \& Hutton, R. eds. 1999. The Cerne Giant; An Antiquity on Trial. Oxford: Oxbow Books.

Deetz, J. F. 1977. In Small Things Forgotten: The Archaeology of Early American Life. New York: Anchor Press. 
Deetz, J. F. 1988. Material Culture and World View in Colonial Anglo-America. In: M. P. Leone and P. PotterJnr., eds. Recovery of Meaning: Historical Archaeology in the Eastern United States. Washington: Smithsonian Press, pp. 219-34.

Dégh, L. 1996. What is a Belief Legend? Folklore, 106: 33-46.

Dorson, R. M. 1950. Folklore and Fakelore. American Mercury, 70: 335-43.

Dorson, R. M. 1959. A Theory for American Folklore. Journal of American Folklore, 72: 336-44.

Dorson, R. M. 1962. Folklore and the National Defence Education Act. Journal of American Folklore, 75:160-64.

Dorson, R. M. 1968. The British Folklorists: A History. London: Routledge.

Dorson, R. M. 1973. Is Folklore a Discipline? Folklore, 84(3): 177-205.

Edgeworth, M. 2003. Acts of Discovery: An Ethnography of Archaeological Practice. Oxford: Archaeopress.

Edgeworth, M. ed. 2006. Ethnographies of Archaeological Practice: Cultural Encounters, Material Transformations. Lanham: Altamira Press.

Edgeworth, M. 2010. On the Boundary: New Perspectives from Ethnography of Archaeology. In: D. Garrow and T. Yarrow, eds. Archaeology and Anthropology: Understanding Similarity, Exploring Difference. Oxford: Oxbow, pp. 53-68.

Falk, A.-B. \& Kyritz, D. M. eds. 2008. Folk Beliefs and Practice in Medieval Lives. Oxford: Archaeopress.

Fleure, H. J. 1948. Archaeology and Folklore. Folklore, 59(2): 69-74.

Folk-Lore Society, The. 1878. Rules. The Folk-Lore Record, 1: viii-ix.

Fredheim, L.H. 2020. Decoupling 'Open' and 'Ethical' Archaeologies: Rethinking Deficits and Expertise for Ethical Public Participation in Archaeology and Heritage. Norwegian Archaeological Review, doi:10.1080/ 00293652.2020.1738540.

Gazin-Schwartz, A. \& Holtorf, C. J. eds. 1999. Archaeology and Folklore. London: Routledge.

Glassie, H. 1969. Pattern in the Material Folk Culture of the Eastern United States. Philadelphia: University of Pennsylvania Press.

Glassie, H. 1975. Folk Housing in Middle Virginia. Knoxville: University of Tennessee Press.

Grinsell, L. V. 1937. Some Aspects of the Folklore of Prehistoric Monuments. Folklore, 48(3): 24559.

Grinsell, L. V. 1939. Scheme for Recording to Folklore of Prehistoric Remains. Folklore, 50(4): 32332.

Grinsell, L. V. 1976a. Folklore of Prehistoric Sites in Britain. Newton Abbot: David and Charles. 
Grinsell, L. V. 1976b. The Legendary History and Folklore of Stonehenge. Folklore, 87(1): 5-20.

Grinsell, L. V. 1980. A Century of the Study of Folklore of Archaeological Sites, and Prospects for the Future. In: V. J. Newall, ed. Folklore Studies in the Twentieth Century: Proceedings of the Centenary Conference of the Folklore Society. Suffolk: D. S. Brewer, pp. 213-17.

Gunnell, T. 2008. Introduction. In: T. Gunnell, ed. Legends and Landscape: Articles Based on Plenary Papers Presented at the 5th Celtic-Nordic-Baltic Folklore Symposium, Reykjavík 2005. Reykjavík: University of Iceland Press, pp. 13-24.

Gunnell, T. 2010. Daisies Rise to Become Oaks: The Politics of Early Folktale Collection in Northern Europe. Folklore, 121(1): 12-37.

Hamilakis, Y. \& Anagnostopoulos, A. 2009. What is Archaeological Ethnography? Public Archaeology, 8(2-3): 65-87.

Hawkes, J. 1968. The Proper Study of Mankind. Antiquity, 42: 255-62.

Hayman, R. 1997. Riddles in Stone: Myths, Archaeology and Ancient Britons. London: The Hambledon Press.

Higham, N. J. 2002. King Arthur: Myth-Making and History. London: Routledge.

Hobsbawm, E. \& Ranger, T. eds. 1983. The Invention of Tradition. Cambridge: Cambridge University Press.

Hodder, I. 1997. 'Always Momentary, Fluid and Flexible': Towards a Reflexive Excavation Methodology. Antiquity, 71: 691-700.

Hodder, I. 2003. Archaeological Reflexivity and the 'Local' Voice. Anthropological Quarterly, 76(1): $55-69$.

Holtorf, C. 2007. Can You Hear Me at the Back? Archaeology, Communication and Society. European Journal of Archaeology, 10(2-3): 149-65.

Johnston, R. \& Marwood, K. 2017. Action Heritage: Research, Communities, Social Justice. International Journal of Heritage Studies, 23(9): 816-31.

Kaufman, N. 2009. Place, Race and Story. London: Routledge.

Knuuttila, S. 2003. Mythscape. In: L. Tarkka, ed. Dynamics of Tradition: Perspectives on Oral Poetry and Folk Belief. Helsinki: Finnish Literature Society, pp. 151-60.

Kulturminneloven, 1978. [The Cultural Heritage Act] [online] [accessed 24 July 2020]. Available at: https://lovdata.no/dokument/NL/lov/1978-06-09-50 (in Norwegian).

Lambeck, M. 2002. The Weight of the Past: Living with History in Mahajanga, Madagascar. New York: Palgrave.

Larsen, K. 1998. Spirit Possession as Historical Narrative: The Production of Identity and Locality in Zanzibar Town. In: N. Lovell, ed. Locality and Belonging. London: Routledge, pp. 125-46.

Leone, M. P. 1973. Archaeology as the Science of Technology: Mormon Town Plans and Fences. In: C. L. Redman, ed. Research and Theory in Current Archaeology. New York: Wiley, pp. 125-50. 
Long, L. 2015. General Introduction. In: L. Long, ed. The Food and Folklore Reader. London: Bloomsbury, pp.1-5.

Lubbock, J. 1865. Pre-Historic Times, as Illustrated by Ancient Remains, and the Manners and Customs of Modern Savages. London: Williams and Norgate.

Lubbock, J. 1870. The Origin of Civilisation and the Primitive Condition of Man. London: Longmans, Green.

Marshall, Y. 2002. What is Community Archaeology? World Archaeology, 34(2): 211-19.

Mason, J. 1999. Haunted Heritage. London: English Heritage.

Mason, R. J. 2000. Archaeology and Native North American Oral Tradition. American Antiquity, 65(2): $239-66$.

Matsuda, A. 2009. Engaging with Archaeology: A Study on the Relationship between Local People and the Excavation of the 'Villa of Augustus' in Somma Vesuviana (Italy). Unpublished $\mathrm{PhD}$ thesis, University College London.

Matsuda, A. 2010. When a Local Legend is (Mis)Appropriated in the Interpretation of an Archaeological Site. Archaeologies: Journal of the World Archaeological Congress, 6(3): 447-67.

Mazo, J. A. 1996. ‘A Good Saxon Compound'. Folklore, 107: 107-08.

McNeill, L. S. \& Tucker, E. eds. 2018. Legend Tripping: A Contemporary Legend Casebook. Logan: Utah State University Press.

Merriman, N. 2002. Archaeology, Heritage and Interpretation. In: B. Cunliffe, W. Davies and C. Renfrew, eds. Archaeology: The Widening Debate. Oxford: The British Academy, pp. 541-65.

Merriman, N. 2004. Introduction: Diversity and Dissonance in Public Archaeology. In: N. Merriman, ed. Public Archaeology. London: Routledge, pp. 1-17.

Muinaismuistolaki, 1963. [The Antiquities Act] [online] [accessed 24 July 2020]. Available at https://www.finlex.fi/ sv/laki/ajantasa/1963/19630295 (in Swedish).

Müller, M. 1865. Comparative Mythology. In: J. F. Rotton, eds. Oxford Essays: Contributed by Members of the University. London: John W. Parker and Son, pp. 1-178.

National Trust, The. 2019. Very Superstitious [online] [accessed 17 April 2020]. Available at: https://www. nationaltrust.org.uk/press-release/very-superstitious-national-trust-calls-on-the-publicto-share-their-tales-of-the-nations-rich-folklore-amid-growing-interest.

Niedermüller, P. 1999. Ethnicity, Nationality, and the Myth of Cultural Heritage: A European View. Journal of Folklore Research, 36(2/3): 243-53.

Noyes, D. 2012. The Social Base of Folklore. In: R. F. Bendix and G. Hasan-Rokem, eds. A Companion to Folklore. Chichester: Wiley-Blackwell, pp. 13-39.

Nyberg, T., Piø, I., Sørensen, P. M. \& Trommer, A. eds. 1985. History and Heroic Tale: A Symposium. Odense: Odense University Press. 
Olsen, B. 2010. In Defense of Things: Archaeology and the Ontology of Objects. Lanham: Rowman \& Littlefield.

Orange, H. 2006. 'We have neglected to ask the punters what they think': Archaeology, Identity and Consumerism at Tintagel. Unpublished MA dissertation, University College London.

Orange, H. \& Laviolette, P. 2010. A Disgruntled Tourist in King Arthur's Court: Archaeology and Identity at Tintagel, Cornwall. Public Archaeology, 9(2): 85-107.

Paphitis, T. 2013. 'Have You Come to Take the King Away?': A Survey of Archaeology and Folklore in Context. Papers from the Institute of Archaeology, 23(1): article 16.

Paphitis, T. 2014. The Place of Folklore in Archaeological Landscapes: Narratives and Identity in Medieval to Modern Britain. Unpublished Doctoral thesis, University College London.

Propp, V. 1968 [1928]. Morphology of the Folktale, ed. L. A. Wagner, trans. L. Scott. Austin: University of Texas Press.

Samuel, R. 1994. Theatres of Memory, Volume I: Past and Present in Contemporary Culture. London: Verso.

Schadla-Hall, T. 1999. Editorial: Public Archaeology. European Journal of Archaeology, 2(2): 14758.

Schnapp, A. 1993. The Discovery of the Past: The Origins of Archaeology. London: British Museum Press.

Shanks, M. \& Tilley, C. 1992. Re-Constructing Archaeology: Theory and Practice, 2nd ed. London: Routledge.

Siikala, A.-L. 2008. Reproducing Social Worlds: The Practice and Ideology of Oral Legends. In: T. Gunnell, ed. Legends and Landscape. Reykjavík: University of Iceland Press, pp. 39-68.

Simpson, J. 2008. A Ghostly View of England's Past. In: T. Gunnell, ed. Legends and Landscape. Reykjavík: University of Iceland Press, pp. 25-38.

Simpson, J. \& Roud, S. 2000. A Dictionary of English Folklore. Oxford: Oxford University Press.

Smith, G. E. 1911. The Ancient Egyptians and their Influence upon the Civilization of Europe. New York: Harper

Smith, L. 2006. Uses of Heritage. London: Routledge.

Sommers, L.K. 2019. Introduction: The Place of Folklore in Historic Preservation. Journal of American Folklore, 132(526): 355-58.

Stewart, C. 2012. Dreaming and Historical Consciousness in Island Greece. Massachusetts: Harvard University Press.

Stroulia, A. \& Sutton, S. B. 2009. Archaeological Sites and Local Places: Connecting the Dots. Public Archaeology, 8(2-3): 124-40.

Symonds, J. 1999. Songs Remembered in Exile? Integrating Unsung Archives of Highland Life. In: A. Gazin-Schwartz and C. Holtorf, eds. Archaeology and Folklore. London: Routledge, pp. 106-28. 
Taussig, M. 1984. History as Sorcery. Representations, 7: 87-109.

Thoms, W. 1846. Folk-Lore. The Athenaeum, 982: 862-63.

Tilley, C. 1989. Archaeology as Socio-Political Action in the Present. In: V. Pinsky and A. Wylie, eds. Critical Traditions in Contemporary Archaeology. Cambridge: Cambridge University Press, pp. 10416.

Tolkien, J. R. R. 1947. On Fairy-Stories. In: C. Tolkien, ed. The Monsters and the Critics and Other Essays. London: Harper Collins, pp. 109-61.

Trigger, B. G. 1984. Alternative Archaeologies: Nationalist, Colonialist, Imperialist. Man, 19: 355-70.

Trigger, B. G. 2006. A History of Archaeological Thought, 2nd ed. Cambridge: Cambridge University Press.

Tylor, E. B. 1865. Researches into the Early History of Mankind and the Development of Civilization. London: John Murray.

Tylor, E. B. 1871. Primitive Culture. London: John Murray.

Ucko, P. 1987. Academic Freedom and Apartheid: The Story of the World Archaeological Congress. London: Duckworth.

Utz, R. 2006. Hic iacet Arthurus? Situating the Medieval King in English Renaissance Memory. In K. Fugelso, ed. Memory and Medievalism. Cambridge: D. S. Brewer, pp. 26-40.

Wallis, R. J. \& Lymer, K. 2001a. Introduction. In: R. J. Wallis and K. Lymer, eds. A Permeability of Boundaries? New Approaches to the Archaeology of Art, Religion and Folklore. Oxford: Archaeopress, pp. xiii-Xviii.

Wallis, R. J. \& Lymer, K. eds. 2001b. A Permeability of Boundaries? New Approaches to the Archaeology of Art, Religion and Folklore. Oxford: Archaeopress.

Woolf, D. B. 1988. The 'Common Voice': History, Folklore and Oral Tradition in Early Modern England. Past and Present, 120: 26-52.

\section{Notes on contributor}

Tina Paphitis gained her PhD from UCL Institute of Archaeology, where she is cur-rently a Teaching Fellow in Heritage and Museum Studies. She is also Assistant Librarian of the Folklore Society and Visiting Researcher in Folklore at the University of Hertfordshire. Her research interests include resituating folklore and folkloristics within archaeological and heritage discourse, exploring folklore as archaeological representation, and public and applied folklore. 